\title{
Pleasure-suffering indicators of nursing work in a hemodialysis nursing service
}

\author{
Indicadores de prazer e sofrimento no trabalho da enfermagem \\ em um serviço de hemodiálise \\ Indicadores de placer y sufrimiento en el trabajo de la \\ enfermería en un servicio de hemodiálisis
}

Francine Cassol Prestes ${ }^{1}$, Carmem Lúcia Colomé Beck² ${ }^{2}$ Tânia Solange Bosi de Souza Magnago ${ }^{3}$, Rosângela Marion da Silva ${ }^{4}$

\footnotetext{
${ }^{1}$ Administrative Technician in Education, Department of Nursing, Universidade Federal de Santa Maria, Santa Maria, RS, Brazil.

${ }^{2}$ Associate Professor, Nursing Program, Universidade Federal de Santa Maria, Santa Maria, RS, Brazil.

${ }^{3}$ Adjunct Professor, Nursing Program, Universidade Federal de Santa Maria, Santa Maria, RS, Brazil.

${ }^{4}$ Assistant Professor, Graduate Nursing Program, Universidade Federal de Santa Maria, Santa Maria, RS, Brazil.
}

\section{ABSTRACT}

Objective: To measure the pleasure and suffering indicators at work and relate them to the socio-demographic and employment characteristics of the nursing staff in a hemodialysis center in southern Brazil. Method: Quantitative research, with 46 workers. We used a self-completed form with demographic and labor data and the Pleasure and Suffering Indicators at Work Scale (PSIWS). We conducted a bivariate and correlation descriptive analysis with significance levels of 5\% using the Epi-Info ${ }^{\circledR}$ and PredictiveAnalytics Software programs. Results: Freedom of Speech was considered critical; other factors were evaluated as satisfactory. The results revealed a possible association between sociodemographic characteristics and work, and pleasure and suffering indicators. There was a correlation between the factors evaluated. Conclusion: Despite the satisfactory evaluation, suffering is present in the studied context, expressed mainly by a lack of Freedom of Speech, with the need for interventions to prevent injury to the health of workers.

\section{DESCRIPTORS}

Nursing; Renal Dyalisis; Burnout, Professional; Occupational Health; Job Satisfaction; Pleasure-Pain Principle. 


\section{INTRODUCTION}

Work occupies a position of centrality in the lives of individuals, thus constituting a fundamental operator in the construction of the subject. Thus, work activity is a construction of meaning, the conquest of identity, continuity and historicizing of men $^{(1)}$.

In the same perspective, work activity can promote health with a pivotal role, or contribute to destabilization, leading the subject to imbalance, which reinforces the premise that work is never neutral with regards to workers' health ${ }^{(2)}$.

This research is based on the theoretical framework of the psychodynamics of work, holding the dynamic relations between the labor organization and the employee's subjective processes as its object of study. In these relationships, suffering plays a key role that articulates health and pathology at the same time. Health implies dealing with impositions and pressures at work that cause psychological instability, while pathology is related to failures in the ways of coping with suffering ${ }^{(3)}$.

Thus, on the one hand, suffering operates as a mobilizer of investments in the transformation of reality, and the possibility of transforming reality, and on the other it gives pleasure to the worker. Thus, experiences of pleasure and suffering are dialectical and inherent in all work settings ${ }^{(2)}$.

In this perspective, work can be a health promoter when creativity is used to transform a situation of suffering, which positively affects the worker's identity since it increases their resistance to the risk of mental and somatic destabilization ${ }^{(3)}$.

Nursing workers often forget to take care of themselves and the space in which they work from worrying over watching other individuals for whom they care for, and this has had repercussions on them becoming ill due to the conditions they are exposed to and the unfavorable environments they are in for the development of their activities ${ }^{(4)}$.

Within the different environments of nursing work, hemodialysis service work stands out. This work has certain specificities, such as the development of activities next to patients in situations of chronic illness and the need of specific knowledge to monitor a procedure with high technical complexity ${ }^{(5)}$.

The experience of the team for long periods with the same patients adds to this, which helps in building and establishing a relationship, but also arouses mixed feelings among workers, which on one hand, makes them feel recognized and valued from demonstrations of affection and caring, but on the other, they are limited in facing the caring needs, the family and financial problems of some patients, which constitute the main differentials in nursing work in this sector ${ }^{(6)}$.

The proposition of this study is also justified in that, despite the growing demand for dialysis services worldwide ${ }^{(7)}$, there are few studies that focus on aspects related to the health of nursing staff in the context of their employment ${ }^{(6)}$. Given the above, the subject of this research is the health of nursing staff working in hemodialysis units and more specifically, the pleasure and suffering indicators related to the work activities in this environment. The objective was to measure the pleasure and suffering indicators at work and relate them to the sociodemographic and work characteristics of the nursing staff in a hemodialysis center in southern Brazil.

\section{METHOD}

This is a quantitative, cross-sectional study conducted in a hemodialysis center located in southern Brazil. This is a privatized intra-hospital service contracted to the Unified Health System (SUS), which provides treatment at two units (headquarters and subsidiary branch) to about 300 patients on a regular hemodialysis program.

The population consisted of 51 nursing workers from the service (six nurses, 33 technicians and 12 nursing assistants). The inclusion criteria were being a member of the nursing team for at least six months, and excluded those workers on vacation or any other type of absence from work during the data collection period from March to April 2011.

Workers who met the inclusion criteria were approached individually in the workplace, informed about the objectives of the study and invited to participate. If they agreed, they were given the research form in a coded envelope, with guidance on how to fill it out. Participants could choose to respond or not respond about the instruments specific to their workplace. Of the 51 nursing workers, 46 participated in the study, and three were excluded; of these, one had less than six months of experience in service and two were removed for health treatment during the period of data collection. The loss $(4.1 \%, n=2)$ corresponded to forms that were returned incomplete.

The survey form contained information regarding demographic information (gender, age, marital status and presence of children under six years of age), labor information (function, work shifts, working time, the presence of another job, work related incidents, need of absence from work for health treatment in the last year and satisfaction with current compensation) and the Pleasure and Suffering Indicators at Work Scale (PSIWS or EIPST in Portuguese). This is one of the four scales from the Labour and Risks of Illness (ITRA), a self-applicable instrument validated in $\mathrm{Brazil}^{\left({ }^{(3)}\right.}$, which evaluates some aspects of the interrelationship between work and the risk of illness ${ }^{(3)}$.

The PSIWS consists of four factors: two evaluate experiences of pleasure at work, and the other two evaluate experiences of suffering. Factors related to pleasure are: Freedom of Speech and Professional Fulfillment; and the factors that evaluate the suffering at work are: Professional Exhaustion and lack of recognition. The scale assesses the occurrence of experiences of pleasure-suffering indicators in the last six months of work, where $0=$ never, $1=$ once, 2 = twice, $3=$ three times, $4=$ four times, $5=$ five times and 6 $=$ six or more times.

We used the Epi-Info ${ }^{\circledR}$ version 6.04 program for data insertion, with independent double entering of the data. After the correction of errors and inconsistencies, the analysis was conducted in the SAWS Statistic ${ }^{\circledR}$ program 
(PredictiveAnalytics Software) version 18.0 for Windows. We conducted a descriptive analysis of the variables, so that the qualitative data were described by absolute and relative frequency, while the quantitative data with normal distribution, mean and standard deviation.

In the PSIWS analysis, factors assessing pleasure such as Freedom of Speech (items 1-8) and Professional fulfillment (items 9-17) were considered positive, therefore the specification, the qualification and how often they are experienced were classified into three different levels, with individual standard deviations, as follows: above $4=$ more positive and satisfactory evaluation; between 3.9 and 2.1 = moderate to critical evaluation; below $2.0=$ rarely to serious evaluation. On the other hand, for factors assessing suffering at work, such as Professional Exhaustion (items 18-24) and Lack of recognition (items 25-32), which are considered negative items, the analysis was performed at the following levels: above $4=$ more negative and critical assessment; between 3.99 and $2.1=$ moderate to critical evaluation; below $2.0=$ less negative to satisfactory assessment.

Bivariate analyzes were performed after. We used the chi-square or Fisher's exact test with significance levels of $5 \%$ for associations between the PSIWS variables and sociodemographic and labor variables (categorical).

The correlation between the PSIWS factors were analyzed using the Spearman correlation coefficient. The strength of association as presented by the correlation coefficient can be classified according to the intensity of their correlation, ranging from +1 to -1 , and is classified per the intensity as follows: $\mathrm{r}=1$ perfect correlation; 0.80 $<\mathrm{r}<1$ very high; $0.60<\mathrm{r}<0.80$ high; $0.40<\mathrm{r}<0.60$ moderate; $0.20<\mathrm{r}<0.40$ low; $0<\mathrm{r}<0.20$ very low; $\mathrm{r}$ $=0$ null $^{(8)}$. We evaluated the reliability of the factors by estimating the internal consistency through Cronbach's alpha coefficient.

The research followed ethical guidelines for research involving human beings established by Resolution 466/12 of the National Health Council, and we obtained permission for performing the research from the Research Ethics Committee of the research institution, and the Presentation Certificate of Ethics Assessment (CAAE), under number 0364.0.243.000-10. All participants read and signed twoway copies of the Informed Consent.

\section{RESULTS}

There was a predominance of females among the respondents $(80.4 \%, \mathrm{n}=37)$, with an average age of 39.9 years $(\mathrm{SD}=10.02)$, nursing technicians $(67.4 \%, \mathrm{n}=31)$, with an average of 10.28 years performance in service $(\mathrm{SD}=6.64)$ and most did not have another job $(73.9 \%$, $\mathrm{n}=34)$. The largest share of workers $(56.5 \%, \mathrm{n}=26)$ said they were $75 \%$ satisfied with the current remuneration, had not suffered an accident at work $(82.6 \% ; n=38)$ and had not missed work for health reasons in the last year $(67.4 \% ; \mathrm{n}=31)$.

Table 1 presents the descriptive statistics, classification and Cronbach's alpha of PSIWS factors.

Table 1 - Descriptive statistics, classification and Cronbach's alpha of PSIWS factors - Santa Maria, RS, Brazil, 2011.

\begin{tabular}{lccccc}
\hline & Factor & Average & Standard Deviation & Classification & Cronbach's Alpha \\
\hline Pleasure & Freedom of Speech & 3.95 & 1.10 & Critical & 0.79 \\
& Professional Fulfillment & 4.84 & 0.79 & Satisfactory & 0.82 \\
& Professional Exhaustion & 1.89 & 1.22 & Satisfactory & 0.86 \\
\hline Suffering & Lack of Recognition & 1.06 & 0.94 & Satisfactory & 0.82 \\
\hline
\end{tabular}

Note: $(\mathrm{N}=46)$.

The Freedom of Speech factor was assessed as critical for the hemodialysis service workers $(\mu=3.95, \mathrm{SD}=1.10)$. The other factors were considered satisfactory. All PSIWS factors showed adequate internal consistency.

Freedom of Speech is the experience of freedom to think, organize and talk about work. Items with more negative evaluation which contributed to the critical evaluation of factors were: trust among coworkers $(\mu=3.26, \mathrm{SD}=1.482)$ and freedom to express my opinions in the workplace $(\mu=3.67$, $\mathrm{SD}=1.851$ ). The items evaluated more positively were: freedom to negotiate what you need with leadership $(\mu=4.72, \mathrm{SD}=$ $1.64)$ and solidarity among coworkers $(\mu=4.15, \mathrm{SD}=1.534)$.

We verified that employees who worked the night shift more critically evaluated Freedom of Speech $(p=0.005)$. We did not identify other statistically significant associations among the variables of interest $(p>0.05)$.
Professional Fulfillment is defined as the experience of professional gratification, pride and identification with the work being done. This factor showed satisfactory assessment for eight of the nine items that comprise it, with I feel pride in what I do $(\mu=5.72, \mathrm{SD}=0.544)$ and professional fulfillment ( $\mu=5.26, \mathrm{SD}=0.905)$ being the main contributors to the experiences of pleasure. The item of recognition was assessed as critical $(\mu=3.65, \mathrm{SD}=1.73)$. There was no significant association between professional fulfillment factor and the sociodemographic and labor variables $(\mathrm{p}>0.05)$.

Professional Exhaustion is reflected by the experience of frustration, insecurity, helplessness, exhaustion and stress at work. The workers surveyed showed no emotional exhaustion, as the evaluation factor was satisfactory. When solely analyzing themselves, there was a more positive and satisfactory assessment considering the items: $f$ ear $(\mu=1.24$, 
$\mathrm{SD}=1.523)$ and uncertainty $(\mu=1.26, \mathrm{SD}=1.512)$. The experiences of stress $(\mu=2.65, \mathrm{SD}=1.595)$, overload $(\mu=2.61$, $\mathrm{SD}=1.832)$ and emotional exhaustion $(\mu=2.50, \mathrm{SD}=1.786)$ were considered critical to moderate, as evaluated by the research participants.

Among the labor variables, we identified a significant association between remuneration satisfaction and the factor of professional exhaustion. The workers who were the least satisfied with their compensation held a more critical evaluation factor $(\mathrm{p}=0.028)$. The remaining variables did not show a significant difference between groups $(p>0.05)$.

The lack of recognition can be translated by the experience of injustice, indignation and devaluation in not being recognized for accomplished work. All items making up this factor achieved satisfactory evaluation. The items discrimination $(\mu=0.35, \mathrm{SD}=0.822)$ and disqualification $(\mu=$ $0.50, \mathrm{SD}=0.913$ ) showed more positive assessment, meaning that these items were not experiences of frequent suffering in the investigated employment context.

With regard to labor variables, we found that employees who worked 6-12 years in service $(\mathrm{p}=0.01)$ and those who had another job $(\mathrm{p}=0.033)$ had a more negative assessment regarding the lack of recognition.

Table 2 shows the Spearman correlation coefficients between the PSIWS variables.

Table 2 - The Spearman correlation coefficients between the variables of PSIWS - Santa Maria, RS, Brazil, 2011.

\begin{tabular}{lllll}
\hline & FS & PF & PE & LR \\
\hline Freedom of speech (FS) & 1 & & & \\
Professional Fulfillment (PF) & $0.67^{* *}$ & 1 & & \\
Professional Exhaustion (PE) & -0.07 & $-0.43^{* *}$ & 1 & \\
Lack of Professional Recognition (LR) & $-0.30^{*}$ & $-0.43^{* *}$ & $0.39^{* *}$ & 1
\end{tabular}

* Significant correlation at the level of $\mathrm{p} \leq 0.05$; ** Correlation significant at the level of $\mathrm{p} \leq 0.01$

Note: $(\mathrm{N}=46)$

Freedom of speech showed high positive correlation with professional fulfillment and low negative correlation with the lack of recognition. Professional fulfillment showed moderate negative correlation with professional exhaustion and lack of recognition. Professional exhaustion showed low positive correlation with the lack of recognition.

\section{DISCUSSION}

The first factor that evaluates the experiences of pleasure (Freedom of Speech) was considered critical by the workers surveyed in this study, a result that is similar to that found with the nursing staff who worked in Intensive Care Units (ICU) of a large public hospital ${ }^{(9)}$. A survey of nurses working in the ICU of a private hospital ${ }^{(10)}$ identified more positive results, since the population investigated evaluated the factor as satisfactory.

A study conducted in Germany ${ }^{(7)}$ found that workers in hemodialysis centers rated their influence and the degree of freedom to be significantly lower, compared to those who worked in hospitals.

A lack of trust among colleagues was also identified in a previous study ${ }^{(9)}$, together with the lack of freedom to express opinions in the workplace are indicators that may affect experiences of pleasure in the investigated scenario.

Research conducted with the nursing staff of a dialysis unit identified the presence animosities, competitive attitudes and relationship problems among some workers ${ }^{(11)}$, which confirms the results shown in this study as to the involvement of experiences of pleasure at work in regards to the lack of trust among coworkers.

It is believed that the freedom to express opinions in the workplace, considered critical by the nursing workers surveyed, may also be limited by the fact that the work is predominantly carried out in collective rooms with patients who undergo the treatment. Therefore, expressing certain opinions in hemodialysis rooms can go against professional ethics, or even expose patients to uncomfortable situations.

On the other hand, one must consider that Freedom of Speech is manifested through speech and action, from the reality experienced in everyday work, and are fundamental aspects in the organization of work, which are reflected in the experiences of pleasure and empowerment of workers ${ }^{(3)}$.

In this study, we identified pleasure in the cooperation among colleagues in the factor of Freedom of Speech. This result was also shown in a survey of nursing technicians of a public emergency hospital, in which participants attributed their pleasure in work from unity among team members and mutual collaboration in activities ${ }^{(12)}$.

Likewise, a study with nursing staff who worked in a French $\mathrm{ICU}^{(13)}$ revealed a significant association between higher social support from colleagues most likely to report a good current state of health, which can reinforce the positive impact of good interpersonal relationships among members of the nursing staff on the health of workers.

Regarding the association of this factor with the variables of interest in the researched service, Freedom of Speech was more critically assessed by workers who worked the night shift. This finding converges with an account of the nurses who worked the night shift at a teaching hospital, who often mentioned the existence of an apparent disregard of the night shift worker's problems by management. This situation caused feelings of discontent and devaluation in the nurses on the understanding that their complaints were not important ${ }^{(14)}$.

Despite their particularites, day and night work periods maintain the same commitments and goals, which are to offer qualified care ${ }^{(15)}$. However, the night shift of the nursing staff may find it difficult to participate in discussions about the organization of work, which typically occur during the day.

This result, which may be related to the fact that the administrative structure of the investigated service works during business hours, needs intervention, since the needs and unmet expectations of the nursing team members can negatively reflect on the care provided ${ }^{(16)}$ and on workers' health.

In this sense, international study confirms the need of health institutions to facilitate organizational structures that minimize the possible negative effects of labor activity on the health of workers; not only from the perspective of occupational health, but also considering patient safety ${ }^{(13)}$. 
The lack of Freedom of Speech for nursing staff, as evidenced in this study, should be considered as a cautionary situation that requires intervention, because in addition to compromising pleasure experienced at work, it can also result in additional suffering and increasing the possibility of illness for workers.

The second factor of professional fulfillment that evaluates the experiences of pleasure at work was considered satisfactory with a positive result by the participants of this study, compared to the critical evaluation factor evidenced by ICU workers ${ }^{(9-10)}$. This comparative is similar to the results of a study conducted in Turkey ${ }^{(17)}$, in which nurses working in dialysis centers had higher professional fulfillment compared to other hospital units, such as intensive care.

In a Brazilian study of nursing staff who work in public emergency units, most participants reported being satisfied with their work. In the same study, workers satisfied with the work had significantly better assessment of their own health ${ }^{(18)}$, which refers to the relevance of considering subjective aspects such as job satisfaction and professional fulfillment in relation to the health of workers.

The results showed that the participants in this study had pleasure at work for the indicators of professional accomplishment and pride in their work. In this sense, a qualitative study ${ }^{(6)}$ found that identifying with work is manifested by liking what they are doing, the recognition, and the possibility of helping the patient through differentiated care, were pleasing experiences reported by nursing workers of a hemodialysis center.

Another study ${ }^{(5)}$ reported that the members of the nursing staff know that their work has fundamental importance for maintaining the lives of patients and they can see it in the clinical improvement of patients after the completion of the hemodialysis treatment at the end of their work shift. According to the authors, materialization of the result of their work is a differential in the context of their work that gives pride, professional fulfillment, personal gratification, well-being and satisfaction to the nursing staff.

The item of recognition was the only indicator of pleasure critically evaluated by nursing workers in the professional fulfillment factor. This review converges with the results found in another study ${ }^{(10)}$, and suggests that this experience is still below the desired level for nursing workers $^{(16)}$.

Similarly, there is convergence with the theoretical background of the psychodynamics of work, which clarifies that, although it is part of the expectations of all workers, satisfactory recognition is hardly ever granted $^{(1)}$.

The results point to a work context in which the nursing staff of the dialysis service experienced pleasure from professional fulfillment. It is believed that this experience should be encouraged, as it constitutes an essential element for maintaining the psychic balance of the employee.

With regard to the factors of suffering, participants satisfactorily evaluated professional exhaustion; this evaluation was more positive and diverges with the results reported by nurses surveyed in other studies ${ }^{(9-10)}$.
Although psychosocial risk was the least mentioned occurrence of a study conducted in a hemodialysis center, some workers said their work produces mental suffering. Suffering was attributed to working in a closed environment, along with depressed patients and the tension generated by the responsibility of taking care of human lives ${ }^{(11)}$. This description refers to the possibility of professional exhaustion of nursing staff in dialysis services, which was not observed in this study.

Regarding the association between the Professional Exhaustion factor and satisfaction with pay variable, we identified that the workers least satisfied with their pay had a more negative factor rating.

In this sense, research carried out in a general hospital where the salaries of nursing staff were considered low and may have related to the presence of double employment in order to supplement their low monthly income. According to the authors, these conditions trigger suffering and lead to the likelihood of worker overload ${ }^{(19)}$, which can also result in Professional Exhaustion, as evidenced in this study.

The above association is also present in the results of an investigation ${ }^{(16)}$ at a public hospital in Rio de Janeiro, pointing to salary and work overload as significant aspects with regard to job dissatisfaction of the members of the nursing team.

As in Brazil, low wages and the insecurity of nursing employment contracts also occur in European countries ${ }^{(20)}$ and $\mathrm{Asia}^{(21)}$. International studies ${ }^{(20-21)}$ show that low pay and little job security may be associated with overload of nursing workers, job dissatisfaction and intention to leave the job.

The second factor that evaluates suffering is the lack of recognition, and all of its items were evaluated satisfactorily by the participants, which may indicate that the suffering experience from the lack of recognition were not frequent in the dialysis service studied.

This result can be considered positive when considering the findings of a study of a private hospital's nursing staff, where recognition of the work done was the most influential factor in job satisfaction, regardless of the professional category $^{(19)}$.

Despite the positive results regarding the lack of recognition, appreciation and recognition of nursing work need to be maintained and constantly stimulated in the studied service, as well as in all other nursing work scenarios.

In analyzing the association factor with the variables of interest, we found that workers who had worked 6-12 years in the service showed a more negative assessment regarding the lack of recognition. Although confounding factors were not assessed in this study, we suggest the possibility that after the initial years of adjustment to working in hemodialysis, nursing workers might encounter a lack of recognition; a suffering experience that seems to be transformed over the years of working in the service, as team members with over 13 years of experience had a satisfactory assessment in this factor.

Regarding the presence of other jobs, workers with dual employment more critically evaluated professional recogni- 
tion compared to those who worked only in hemodialysis services. The work in hospitals involves the organization of services into shifts and duties, which allows for the presence of double jobs and long working hours; common practices as a way to supplement income, and may contribute to the excessive work overload of professional health work ${ }^{(22)}$.

In this sense, it is reiterated that if there were satisfactory working conditions and fair pay compensation for workers in the health area, there would not be the need to maintain other various employment relationships and thereby the consequent overwork would be eliminated ${ }^{(23)}$.

A study of nursing professionals in a public emergency unit identified the number of employment contracts as a risk factor for the impairment of satisfaction with sleep and rest of the participants ${ }^{(24)}$. This requires attention from workers and managers as this is one of the factors that can compromise the quality of nursing care.

Thus, the association observed in this study refers to the fact that professional recognition is also connected to the issue of compensation. Although this variable does not have statistical significance in this factor, the presence of another job indirectly entails the need to supplement their income, and also lends to the possibility of workers suffering from lack of recognition.

In addition, the need for supplementary income through another employment due to low salaries of nursing can increase the risks to workers' health, making it necessary to also investigate other consequences, such as those related to the care process ${ }^{(25)}$.

It is evident from the above reasons and from general evaluation that a lack of recognition occurred discreetly in the nursing work of this hemodialysis service, but we must consider that this suffering existed and was more pronounced among workers who had worked for 6-12 years in service and had another job.

With respect to correlations between pleasure and suffering factors, we noticed an inverse correlation between professional fulfillment and professional exhaustion. A study of nursing staff in Finland, Norway and Sweden found that most participants were satisfied with their profession, but workers with higher workload had lower professional fulfillment and the intention to leave their job ${ }^{(26)}$.

The authors ${ }^{(27)}$ state that the workload and the limited time for rest compromise the mental health of nursing workers and can lead to personal problems, difficulty in interpersonal relations and a decrease in the performance of professional activities.

Regarding this, research conducted with the nursing staff of a medical unit identified that the workload was one of the determining factors for the occurrence of occupational accidents involving biological exposure ${ }^{(28)}$.

Professional exhaustion has important repercussions that can influence new situations of suffering and compromise other areas of worker's lives, including experiences of pleasure at work such as professional fulfillment.

The experiences of pleasure through Professional Fulfillment and Freedom of Speech were highly correlated in this study. This result reinforces that the subjective aspects related to the working activity in health services need to be considered, as they have influence on the quality of the environment and the work itself ${ }^{(12)}$. Thus, the stimulus to the experiences of pleasure, especially through recognition and freedom of speech can have a positive impact, not only on the health of workers, but also the quality of the work.

From this perspective, it can be inferred that the experiences of pleasure at work relate to and enable other feelings of well-being, which can provide additional satisfaction to the worker and consequently, health protection.

The suffering factors of professional exhaustion and lack of recognition at work were negatively correlated with the pleasure of Professional Fulfillment. By analyzing these correlations, it is necessary to consider that the hospital environment is configured as an arduous and unhealthy workplace, with high occupational hazards ${ }^{(22)}$, which refers to the suffering experience and possibility of professional exhaustion of workers.

A study of the factors attributed by nursing professionals to absence from work identified elements such as the burden on workers, inadequate resources, lack of incentive for professional development and qualification, poor salaries and excessive working hours. According to the authors, these elements contribute to the dissatisfaction of health professionals in front of non-recognition of their effort, the lack of appreciation and exposure to inappropriate working conditions $^{(29)}$.

Similar aspects were described in an Iranian study, which identified the workload and the physical and mental exhaustion of nurses as factors of frustration and motivation for leaving the profession. In the same study, recognition was considered as a facilitator in nursing work ${ }^{(30)}$.

The results shown in this study confirm that suffering can be enhanced when there is a lack of recognition of the effort invested to get the job done. Thus, recognition constitutes a central element for professional development and establishment of the psychological integrity of the worker, enabling the attribution of meaning to the suffering experienced and thus its conversion into pleasure ${ }^{(3)}$. Therefore, it identifies the convergence of the results with the theoretical framework of psychodynamic work, to the extent that pleasure and suffering make up a single construct ${ }^{(3)}$.

The methodological limitations of this study are related to the size of the study population and the fact that the study was performed in a single dialysis service. These aspects need to be reassessed in new research to enable the realization of further analysis or to compare the results already found.

\section{CONCLUSION}

The nursing staff of the researched dialysis service considered the factors of freedom of speech critical, while professional fulfillment, professional exhaustion and lack of recognition were evaluated satisfactorily. Thus, the pleasure related to work activity stood out in the context of the work investigated.

Regarding the association between indicators of pleasure and suffering to socio-demographic and employment 
characteristics, we found a significant association between the night shift work and the impairment of Freedom of Speech. Similarly, the workers who were least satisfied with their remuneration were the ones that more critically assessed professional exhaustion. Suffering from lack of recognition was found to be associated with 6-12 years of working in the service and the presence of another job.

The impairment of the experiences of pleasure in nursing work at the hemodialysis center expressed by the lack of Freedom of Speech was a highlighted aspect, and requires intervention by the service managers in order to avoid harm to workers' health. In this sense, a possible first step would be to provide listening and discussion spaces for the individual and the collective where workers could express and socialize experiences and feelings related to work activity.

The presence of correlation between the PSIWS factors signals the convergence of the study results with the theoretical framework of psychodynamic work. Although
PSIWS was not specifically constructed to evaluate the experiences of pleasure and suffering in nursing workers, it was internally consistent when applied to this population. The use of the instrument was useful, as it enabled the realization of an assessment that may be developed with the use of qualitative techniques and application of other instruments.

As for possible contributions of the study, the authors mention increasing the awareness on the theme of nursing workers' health in hemodialysis services, a scenario that needs to be explored more in Brazilian studies, and the inclusion of new data that can support discussions related to pleasure and suffering at work. In addition, the results of this study advance scientific knowledge and suggest that despite having a work context where pleasure prevails, there are aspects of work organization such as Freedom of Speech and the recognition of the work that need to be (re)designed in order to minimize the harm to workers' overall health.

\section{RESUMO}

Objetivo: Mensurar os indicadores de prazer e sofrimento no trabalho e relacioná-los com as características sociodemográficas e laborais dos trabalhadores de enfermagem de um serviço de hemodiálise do sul do Brasil. Método: Pesquisa quantitativa, com 46 trabalhadores. Utilizou-se um formulário autopreenchível com dados sociodemográficos e laborais e a Escala de Indicadores de Prazer e Sofrimento no Trabalho. Realizou-se a análise descritiva, bivariada e correlacional, com níveis de significância de 5\%, utilizando-se os programas Epiinfo ${ }^{\circledR}$ e PredictiveAnalytics Software. Resultados: A liberdade de expressão foi considerada crítica; os demais fatores foram avaliados satisfatoriamente. Evidenciou-se possível associação entre as características sociodemográficas e laborais e os indicadores de prazer e sofrimento. Houve correlação entre os fatores avaliados. Conclusão: Apesar da avaliação satisfatória, o sofrimento está presente no contexto pesquisado, manifestado principalmente pela falta de liberdade de expressão, havendo a necessidade de intervenções a fim de evitar prejuízo à saúde dos trabalhadores.

\section{DESCRITORES}

Enfermagem; Diálise Renal; Esgotamento Profissional; Saúde do Trabalhador; Satisfação no Trabalho; Princípio do Prazer-Desprazer.

\section{RESUMEN}

Objetivo: Medir los indicadores de placer y sufrimiento en el trabajo y relacionarlos con las características sociodemográficas y laborales de los trabajadores de enfermería de un servicio de hemodiálisis del sur de Brasil. Método: Investigación cuantitativa, con 46 trabajadores. Se utilizó un formulario autorrellenable con datos sociodemográficos y laborales y la Escala de Indicadores de Placer y Sufrimiento en el Trabajo. Se llevó a cabo el análisis descriptivo, bivariado y correlacional, con niveles de significación del 5\%, utilizándose los programas Epi-info ${ }^{\circledR}$ y PredictiveAnalytics Software. Resultados: La libertad de expresión fue considerada crítica: los demás factores fueron evaluados satisfactoriamente. Se evidenció posible la asociación entre las características sociodemográficas y laborales y los indicadores de placer y sufrimiento. Hubo correlación entre los factores evaluados. Conclusión: Pese a la evaluación satisfactoria, el sufrimiento está presente en el marco investigado, especialmente manifiesto por la falta de libertad de expresión, habiendo la necesidad de intervenciones a fin de evitar perjuicio a la salud de los trabajadores.

\section{DESCRIPTORES}

Enfermería; Diálisis Renal; Agotamiento Profesional; Salud Laboral; Satisfacción en el Trabajo; Principio de Dolor-Placer.

\section{REFERERENCES}

1. Dejours C, Abdoucheli E, Jayet C. Psicodinâmica do trabalho: contribuições da Escola Dejouriana à análise da relação prazer, sofrimento e trabalho. São Paulo: Atlas; 2014.

2. Dejours C. A loucura do trabalho: estudo de psicopatologia do trabalho. São Paulo: Cortez-Oboré; 2009.

3. Mendes AM. Psicodinâmica do trabalho: teoria, método e pesquisas. São Paulo: Casa do Psicólogo; 2007.

4. Ribeiro RP, Martins JT, Marziale MHP, Robazzi MLCC. Work-related illness in nursing: an integrative review. Rev Esc Enferm USP. 2012;46(2):495-504.

5. Prestes FC, Beck CLC, Tavares JP, Silva RM, Cordenuzzi OCP, Burg G, et al. Percepção dos trabalhadores de enfermagem sobre a dinâmica do trabalho e os pacientes em um serviço de hemodiálise. Texto Contexto Enferm [Internet]. 2011 [citado 2013 out. 18]; 20(1):25-32. Disponível em: http://www.scielo.br/pdf/tce/v20n1/03.pdf

6. Prestes FC, Beck CLC, Silva RM, Tavares JP, Camponogara S, Burg G. Prazer-sofrimento dos trabalhadores de enfermagem de um serviço de hemodiálise. Rev Gaúcha Enferm. 2010;31(4):738-45. 
7. Kersten M, Kozak A, Wendeler D, Paderow L, Nübling M, Nienhaus A. Psychological stress and strain on employees in dialysis facilities: a cross-sectional study with the Copenhagen Psychosocial Questionnaire. J Occup Med Toxicol. 2014; 9(1):4.

8. Hair JF, Anderson RE, Tatham RL, Black WC. Análise multivariada de dados. Porto Alegre: Artmed; 2009.

9. Shimizu HE, Couto DT, Merchan-Hamann E. Pleasure and suffering in intensive care unit nursing staff. Rev Latino Am Enfermagem. 2011;19(3):565-72.

10. Campos JF, David HMSL, Souza NVDO. Pleasure and suffering: assessment of intensivist nurses in the perspective of work psychodynamics. Esc Anna Nery Rev Enferm. 2014;18(1):90-5.

11. Morais EM, Fontana RT. Dialytic unit as a scenario of exposure to risk. J Res Fundam Care Online [Internet]. 2014 [cited 2014 Nov 02];6(2):539-549. Available from: http://www.seer.unirio.br/index.php/cuidadofundamental/article/view/2648/pdf_1238

12. Garcia AB, Dellaroza MSG, Haddad MCL, Pachemshy LR. Prazer no trabalho de técnicos de enfermagem do pronto-socorro de um hospital universitário público. Rev Gaúcha Enferm [Internet]. 2012 [cited 2014 nov. 02];33(2):153-9. Disponível em: http:// http://www.scielo.br/ $\mathrm{pdf} / \mathrm{rgenf} / \mathrm{v} 33 \mathrm{n} 2 / 22 . \mathrm{pdf}$

13. Jones G, Hocine M, Salomon J, Dab W, Temime L. Demographic and occupational predictors of stress and fatigue in French intensive-care registered nurses and nurses' aides: cross-sectional study. Int J Nurs Stud. 2015;52(1):250-9.

14. Veiga KCG, Fernandes JD, Paiva MS. Análise fatorial de correspondência das representações sociais sobre o trabalho noturno da enfermeira. Rev Bras Enferm [Internet]. 2013 [citado 2014 nov. 02];66(1):18-24. Disponível em: http://www.scielo.br/pdf/reben/v66n1/v66n1a03.pdf

15. Oro J, Matos E. Possibilities and limits of organization of nursing work in the comprehensive care model in a hospital institution. Texto Contexto Enferm [Internet]. 2013 [cited 2014 Nov 03];22(2):500-8. Available from: http://www.scielo.br/pdf/tce/v22n2/en_v22n2a28.pdf

16. Regis LFLV, Porto IS. Basic human needs of nursing professional: situations of (dis) satisfaction at work. Rev Esc Enferm USP [Internet]. 2011 [cited 2014 June 20];45 (2):334-41. Available from: http://www.scielo.br/pdf/reeusp/v45n2/en_v45n2a04.pdf

17. Kapucu SS, Akkus Y, Akidemir N, Karacan Y. The burnout and exhaustion levels of nurses working in hemodialysis units. J Renal Care. 2009;25(3):134-40

18. Theme Filha MM, Costa MAS, Guilam MCR. Occupational stress and self-rated health among nurses. Rev Latino Am Enfermagem [Internet]. 2013 [cited 2014 Dec 09];21(2):475-83. Available from: http://www.scielo.br/pdf/rlae/v21n2/0104-1169-rlae-21-02-0475.pdf

19. Rodrigues EP, Rodrigues US, Oliveira LMM, Laudano RCS, Sobrinho CLN. Prevalence of common mental disorders in nursing workers at a hospital of Bahia. Rev Bras Enferm [Internet]. 2014 [cited 2014 Nov 02];67(2):296-301. Available from: http://www.scielo.br/pdf/reben/ v67n2/0034-7167-reben-67-02-0296.pdf

20. Cañadas-De la Fuente GA, Vargas C, San Luis C, García I, Cañadas GR, De la Fuente El. Risk factors and prevalence of burnout syndrome in the nursing profession. Int J Nurs Stud. 2015;52(1):240-9.

21. Shang J, You L, Ma C, Altares D, Sloane DM, Aiken LH. Nurse employment contracts in Chinese hospitals: impact of inequitable benefit structures on nurse and patient satisfaction. Hum Resour Health [serial on the Internet]. 2014 [cited 2014 Dec 09];12:1. Available from: http://www.ncbi.nlm.nih.gov/pmc/articles/PMC3896777/

22. Monteiro JK, Oliveira ALL, Ribeiro CS, Grisa GH, Agostini N. Adoecimento psíquico de trabalhadores de Unidades de Terapia Intensiva. Psicol Ciênc Prof [Internet]. 2013 [citado 2014 set. 04];33(2):366-79. Disponível em: http://www.scielo.br/pdf/pcp/v33n2/v33n2a09.pdf

23. Robazzi MLCC, Mauro MYC, Secco IAO, Dalri RCMB, Freitas FCT, Terra FS, et al. Alterações na saúde decorrentes do excesso de trabalho entre trabalhadores da área de saúde. Rev Enferm UERJ. 2012;20(4):526-32.

24. Kogien M, Cedaro JJ. Public emergency department: the psychosocial impact on the physical domain of quality of life of nursing professionals. Rev Latino Am Enfermagem. 2014;22(1):51-8.

25. Griep RH, Fonseca MJM, Melo ECP, Portela LF, Rotenberg L. Enfermeiros dos grandes hospitais públicos no Rio de Janeiro: características sociodemográficas e relacionadas ao trabalho. Rev Bras Enferm. 2013;66(n.esp):151-7.

26. Lindqvist R, Smeds Alenius L, Runesdotter S, Ensio A, Jylhä V, Kinnunen J, et al. Organization of nursing care in three Nordic countries: relationships between nurses' workload, level of involvement in direct patient care, job satisfaction, and intention to leave. BMC Nurs [Internet]. 2014 [cited 2014 Dec 10];13:27. Available from: http://www.biomedcentral.com/content/pdf/1472-6955-13-27.pdf

27. Mauro MYC, Paz AF, Mauro CCC, Pinheiro MAS, Silva VG. Condições de trabalho da enfermagem nas enfermarias de um hospital universitário. Esc Anna Nery Rev Enferm. 2010;14(2):244-52.

28. Soares LG, Sarquis LMM, Kirchhof ALC, Felli VEA. Multicausalidade nos acidentes de trabalho da enfermagem com material biológico. Rev Bras Enferm. 2013;66(6):854-9.

29. Abreu RMD, Gonçalves RMDA, Simões ALA. Motivos atribuídos por profissionais de uma Unidade de Terapia Intensiva para ausência ao trabalho. Rev Bras Enferm. 2014;67(3):386-93.

30. Jafaraghaee F, Mehrdad N, Parvizy S. Influencing factors on professional commitment in Iranian nurses: a qualitative study. Iran J Nurs Midwifery Res [Internet]. 2014 [cited 2014 Dec 09];19(3):301-8. Available from: http://www.ncbi.nlm.nih.gov/pmc/articles/PMC4061633/ 